\title{
Effect of pectin, wheat bran and cellulose on serum lipids and lipoproteins in rats fed on a low- or high-fat diet
}

\author{
BY JEAN LOUIS VIGNE ${ }^{1}$, DENIS LAIRON ${ }^{1 *}$, PATRICK BOREL ${ }^{1}$, \\ HENRI PORTUGAL ${ }^{2}$, ANNE-MARIE PAULI', \\ JACQUES CHRISTIAN HAUTON ${ }^{1}$ AND HUGUETTE LAFONT ${ }^{1}$ \\ ${ }^{1}$ Unité 130-INSERM (Institut National de la Santé et de la Recherche Médicale), \\ 10 avenue Viton, 13009 Marseille, France \\ ${ }^{2}$ Laboratoire Central, Hôpital Ste-Marguerite, 13009 Marseille, France
}

\section{(Received 30 December 1986 - Accepted 17 July 1987)}

\begin{abstract}
1. Four groups of adult male Sprague-Dawley rats were fed for 6 weeks on a diet with a low-fat content $(50 \mathrm{~g} / \mathrm{kg})$ and another four groups were given a diet rich in fat $(250 \mathrm{~g} / \mathrm{kg})$ and cholesterol $(12 \mathrm{~g} / \mathrm{kg})$. In both cases, the basal diets were either fibre-depleted or supplemented with cellulose $(60 \mathrm{~g} / \mathrm{kg})$, wheat bran $(100 \mathrm{~g} / \mathrm{kg})$ or low-methoxyl pectin $(100 \mathrm{~g} / \mathrm{kg})$.

2. Low-methoxyl pectin displayed the most hypocholesterolaemic effect and decreased the cholesterol content of the very-low-density lipoproteins (VLDL) and low-density lipoproteins (LDL), when the low-fat diet was given. When rats were fed on the high-fat diet, pectin no longer had a hypocholesterolaemic effect but still decreased the VLDL-cholesterol content. Pectin lowered serum triglyceride and VLDL-trigylceride levels only when the lowfat diet was given.

3. Wheat bran exerted no hypocholesterolaemic effect in rats fed on the low- and high-fat diets, but decreased the cholesterol content of VLDL and lowered serum triglycerides and VLDL-tryglycerides when the high-fat diet was given.

4. Purified cellulose had no significant effect on plasma lipids.

5. As shown by multivariance analysis, low-methoxyl pectin and wheat bran both beneficially modified the serum triglyceride and cholesterol variables except VLDL-triglycerides. However, the magnitude of the effect of each individual type of fibre was dependent on the fat and cholesterol content of the diet, suggesting the existence of different mechanisms of action.
\end{abstract}

Extensive studies on experimental animals indicated that the addition of different types of dietary fibre may have different effects on cholesterol metabolism (Anderson \& Chen, 1979; Kay, 1982). It has been shown that, in general, pectins significantly decrease the concentration of serum cholesterol in rats whereas wheat bran and cellulose have a variable influence. Most authors have found that wheat bran decreases liver cholesterol storage in rats (Chen \& Anderson, 1979 a; Van Beresteyn et al. 1979; Nomani et al. 1981; Sacquet et al. 1982; Schneeman et al. 1984), and reductions in serum cholesterol concentrations induced by other kinds of fibres are accompanied by decreases in cholesterol content of the liver (Wells \& Ershoff, 1961; Leveille \& Sauberlich, 1966; Chang \& Johnson, 1976; Tsai et al. 1976; Rotenberg \& Jakobsen, 1978; Chen \& Anderson, $1979 a, b$; Judd \& Truswell, 1985; Sacquet et al. 1985). Furthermore, it has been found that the large amount of fibre ingested by black Africans (Trowell, 1972) or some people in industrialized countries (Kromhout et al. 1982) might be an important factor in the low incidence of coronary heart disease observed in these populations. Based on these observations, it has been suggested that a high dietary fibre intake might protect against atherosclerosis (Kritchevsky \& Tepper, 1968; Trowell, 1972).

During the last decade, increasing interest has been focussed on the differential atherogenic potential of various lipoprotein classes. Results of human studies have shown that the concentration of cholesterol in high-density lipoproteins (HDL) might be inversely

\footnotetext{
* For reprints.
} 
Table 1. Composition of experimental diets $(\mathrm{g} / \mathrm{kg}$ dry weight) and final weights of rats $(\mathrm{g})$

\begin{tabular}{lrrrrrrrr}
\hline Groups* $\ldots$ & SO & SC & SP & SB & HFCO & HFCC & HFCP & HFCB \\
\hline Casein & 230 & 230 & 230 & 230 & 230 & 230 & 230 & 230 \\
Lipids & 50 & 50 & 50 & 50 & 250 & 250 & 250 & 250 \\
Cholesterol & 0 & 0 & 0 & 0 & 12 & 12 & 12 & 12 \\
Wheat glucose & 310 & 310 & 310 & 310 & 200 & 200 & 200 & 200 \\
Wheat starch & 330 & 270 & 230 & 230 & 220 & 160 & 128 & 128 \\
Minerals $\dagger$ & 70 & 70 & 70 & 70 & 70 & 70 & 70 & 70 \\
Vitamins & 10 & 10 & 10 & 10 & 10 & 10 & 10 & 10 \\
Fibre & 0 & 60 & 100 & 100 & 0 & 60 & 100 & 100 \\
Energy (MJ/kg) & $16 \cdot 4$ & $15 \cdot 4$ & $14 \cdot 7$ & $14 \cdot 7$ & $20 \cdot 8$ & $19 \cdot 8$ & $19 \cdot 2$ & $19 \cdot 2$ \\
Final wt & $393^{\mathrm{a}}$ & $373^{\mathrm{a}, \mathrm{b}}$ & $361^{\mathrm{b}}$ & $382^{\mathrm{a}}$ & $426^{\mathrm{c}}$ & $431^{\mathrm{c}}$ & $431^{\mathrm{c}}$ & $444^{\mathrm{c}}$ \\
\hline
\end{tabular}

a.b. Mcan values with different superscript letters were significantly different $(P<0-05$; ANOVA).

* SO and HFCO, diets without fibre; SC and HFCC, diets with cellulose; SP and HFCP, diets with lowmethoxyl pectin; SB and HFCB, diets with wheat bran.

$\dagger$ Provided (g/kg diet): $\mathrm{CaHPO}_{4} 21 \cdot 5, \mathrm{KCl} 5, \mathrm{NaCl} 5, \mathrm{MgSO}_{4} 2 \cdot 50 ; \mathrm{Fe}_{2} \mathrm{O}_{3} 0 \cdot 15, \mathrm{FeSO}_{4} .7 \mathrm{H}_{2} \mathrm{O} 0 \cdot 25$, $\mathrm{MnSO}_{4} . \mathrm{H}_{2} \mathrm{O} 0.12, \mathrm{CuSO}_{4} .5 \mathrm{H}_{2} \mathrm{O} 0.025, \mathrm{CoSO}_{4} .7 \mathrm{H}_{2} \mathrm{O} 2 \times 10^{-4}, \mathrm{ZnSO}_{4} .7 \mathrm{H}_{2} \mathrm{O} 0.1$, stabilized KI $4 \times 10^{-4}, \mathrm{NaF}^{2}$ 0.012 .

$\mp$ Provided $(\mathrm{g} / \mathrm{kg}$ diet $)$ : retinol $6.8 \times 10^{-6}$, cholecalciferol $1.5 \times 10^{-6}$, thiamin 0.02 , riboflavin 0.015 , nicotinamide $0 \cdot 035$, pyridoxine $0 \cdot 01$, carnitine $0 \cdot 15$, cyanocobalamin $5 \times 10^{-5}$, ascorbic acid $0 \cdot 8, \alpha$-tocopherol $0 \cdot 17$, menadione 0.04 , nicotinic acid $0 \cdot 10$, choline $1 \cdot 36$, pteroylmonoglutamic acid $5 \times 10^{-6}$, p-aminobenzoic acid 0.05 , biotin $3 \times 10^{-4}$.

correlated with the incidence of cardiovascular diseases (Miller et al. 1976; Gordon et al. 1977). Because fibre influences the cholesterol concentration in serum and liver, fibre might also influence the lipid composition of lipoproteins. However, most studies devoted to the effects of dietary fibre on the lipid concentrations in lipoproteins of rats have been performed without consideration of the fat content of the diets. Conflicting results might thus largely be due to this factor. Since it is well-known that dietary fibre and cholesterol intakes modify lipoprotein pattern, the hypothesis could be made that the level of lipid intake may modify the influence of various fibres on lipid metabolism.

The present investigation was therefore undertaken to evaluate the influence of lowmethoxyl pectin and wheat bran on the lipid composition of the different classes of lipoproteins in rats fed on a balanced diet or a diet rich in saturated fats and cholesterol. Results from these groups were compared with those of two different control groups in which rats were fed on either a fibre-depleted diet or a diet containing cellulose as an indigestible agent.

\section{MATERIALS AND METHODS \\ Experimental conditions}

Adult male Sprague-Dawley rats (IFFA CREDO, l'Arbresle, France) were used in the present study and were segregated into eight groups of ten rats each. The rats were of equal average weight (350 (SE 10))g and were housed in stainless-steel cages in an air-conditioned room (temperature $21^{\circ}$, humidity $50 \%$ ) which was kept on a $12 \mathrm{~h}$ light $-12 \mathrm{~h}$ dark cycle. Diets and water were supplied ad lib. The experimental diets were given for 6 weeks. The detailed composition of the diets (UAR, Villemoisson/Orge) are given in Table 1. Four groups (series S) received a standard balanced diet with a normal low-fat content $(50 \mathrm{~g} / \mathrm{kg}$ ), and four other groups (series HFC) received a high-fat $(250 \mathrm{~g} / \mathrm{kg}$ ) and high-cholesterol $(12 \mathrm{~g} / \mathrm{kg})$ diet. Equal quantities of vegetable and animal lipids were used in both series (fatty acid content, $\mathrm{mg} / \mathrm{g}$ total fatty acid: $16: 0,201 ; 16: 1,48 ; 18: 0,16 ; 18: 1,192$; 
$18: 2 n-6,494 ; 18: 3 n-3,28)$. The fat supplement in series HFC was in the form of lard (fatty acid content, $\mathrm{mg} / \mathrm{g}$ total fatty acid: $16: 0,267 ; 16: 1,24 ; 18: 0,125 ; 18: 1,413 ; 18: 2$, 148).

Groups SO and HFCO were fed on diets containing no dietary fibre. Groups SC and HFCC were fed on diets supplemented with $60 \mathrm{~g}$ cellulose $/ \mathrm{kg}$. The diets of groups SP and HFCP were supplemented with $100 \mathrm{~g}$ low-methoxyl (43\% esterification) pectin (Unipectine, France) $/ \mathrm{kg}$. The diet of groups SB and HFCB contained a supplement of $100 \mathrm{~g}$ wheat bran (ARIA, Paris) $/ \mathrm{kg}$, with a standard particle size distribution (mean $540 \mu \mathrm{m}$ ).

\section{Serum sampling}

At the time of the experiment, the rats were fasted for $24 \mathrm{~h}$, weighed and then killed by total exsanguination. Blood was drawn by abdominal aorta puncture under diethyl ether anaesthesia, then serum was prepared by centrifugation.

\section{Lipoproteins}

Serum ( $1 \mathrm{ml}$ ) was overlayed with $1 \mathrm{ml} 0 \cdot 15 \mathrm{M}$-sodium chloride solution and centrifuged in a $2 \mathrm{ml}$ centrifuge tube for $18 \mathrm{~h}$ at $38000 \mathrm{rev} . / \mathrm{min}$ in a 40.3 rotor of a L-75 Beckman ultracentrifuge. Very-low-density lipoproteins (VLDL; density $\leqslant 1.006 \mathrm{~g} / \mathrm{ml}$ ) were separated by a tube-slicing technique (Havel et al. 1955) from lipoproteins of higher densities. HDL were separated from VLDL and low-density lipoproteins (LDL) by the heparinmanganese precipitation method (Burstein et al. 1970). Quantification of cholesterol in serum, and VLDL serum fraction, and the heparin-Mn supernatant (containing HDL) allowed calculation of the LDL-cholesterol concentration. Conventional precipitation of apo E-rich HDL by the heparin-Mn reagent has been suggested but it was demonstrated that this reagent preferentially precipitates apo $\mathrm{E}$ associated with lipoproteins containing apo B while leaving the fraction of HDL containing apo E (Gibson et al. 1984).

\section{Assays}

Total cholesterol and triglycerides in serum and in the prepared fractions were assayed by the Technicon Auto-analyzer method (Rush et al. 1970). Phospholipids in serum were assayed by an automated method (Amic et al. 1972).

\section{Statistics}

Results were statistically evaluated by analysis of variance (ANOVA) and multivariance analysis and multicomparison methods using contrast analysis (MANOVA).

\section{RESULTS}

\section{Body-weight gain}

As shown in Table 1, the weight gain was similar in the groups given the standard low-fat diet (series S) except for the group supplemented with pectin (SP) whose mean final weight was significantly lower than that of groups SO (cellulose) and SB (wheat bran). On the other hand, the high-fat cholesterol diets (series HFC) induced a much higher final weight without any difference between the four experimental groups.

\section{Serum lipids and lipoproteins in rats fed on standard diets}

Differences between the four groups fed on the standard diet are given in Table 2. Serum cholesterol and triglycerides were lower in the SP group (100 g pectin $/ \mathrm{kg}$ enriched) compared with the SC group ( $60 \mathrm{~g}$ cellulose/ $\mathrm{kg}$ enriched). Serum phospholipids did not change significantly (values not shown). The SP group also differed from the SC group 
Table 2. Effects of dietary fibres on serum and lipoprotein triglycerides and cholesterol in rats fed on a balanced standard diet $(50 \mathrm{~g}$ fat $/ \mathrm{kg})$

(Mean values with their standard errors for nine determinations)

\begin{tabular}{|c|c|c|c|c|c|c|c|c|}
\hline \multirow[t]{2}{*}{ Diet... } & \multicolumn{2}{|c|}{ SO } & \multicolumn{2}{|c|}{$\mathrm{SC}$} & \multicolumn{2}{|c|}{ SP } & \multicolumn{2}{|c|}{ SB } \\
\hline & Mean & $\mathbf{S E}$ & Mean & $\mathbf{S E}$ & Mean & $\mathrm{SE}$ & Mean & $\mathrm{SE}$ \\
\hline \multicolumn{9}{|l|}{ Triglycerides } \\
\hline Serum (mmol/1) & $1 \cdot 16^{\mathrm{a}, \mathrm{b}}$ & $0 \cdot 31$ & $1 \cdot 42^{\mathrm{a}}$ & 0.26 & $0.65^{\circ}$ & $0 \cdot 18$ & $0 \cdot 87^{\mathrm{a}, \mathrm{b}}$ & $0 \cdot 14$ \\
\hline VLDL (mmol/1) & $0.93^{\mathrm{a}, \mathrm{c}}$ & $0 \cdot 24$ & $1 \cdot 21^{\mathrm{a}}$ & 0.22 & $0.59^{b, c}$ & $0 \cdot 18$ & $0.62^{\mathrm{b}, \mathrm{c}}$ & $0 \cdot 13$ \\
\hline \multicolumn{9}{|l|}{ Cholesterol } \\
\hline Serum (mmol/l) & $2 \cdot 11^{\mathrm{a}, \mathrm{b}}$ & $0 \cdot 17$ & $2 \cdot 20^{\mathrm{a}}$ & $0 \cdot 14$ & $1 \cdot 77^{\mathrm{b}}$ & $0 \cdot 10$ & $1.90^{\mathbf{a}, b}$ & 0.06 \\
\hline VLDL $(\mathrm{mmol} / \mathrm{l})$ & $0 \cdot 14^{\mathrm{a}, \mathrm{b}}$ & 0.05 & $0 \cdot 18^{a}$ & 0.05 & $0.09^{\mathrm{b}}$ & 0.01 & $0.09^{a, b}$ & 0.02 \\
\hline $\mathrm{LDL}(\mathrm{mmol} / \mathrm{l})$ & $0 \cdot 47^{\mathrm{a}}$ & $0 \cdot 13$ & $0 \cdot 38^{\mathrm{a}}$ & 0.03 & $0 \cdot 17^{\mathrm{b}}$ & 0.01 & $0 \cdot 41^{\mathrm{a}}$ & 0.07 \\
\hline HDL $(\mathrm{mmol} / \mathrm{l})$ & $1.63^{\mathrm{a}}$ & $0 \cdot 10$ & $1 \cdot 56^{\mathrm{a}}$ & 0.44 & $1 \cdot 53^{a}$ & 0.11 & $1 \cdot 23^{\mathrm{a}}$ & 0.05 \\
\hline VLDL $(\mathrm{mmol} / \mathrm{mol})$ & $59^{\mathrm{a}}$ & 18 & $54^{a}$ & 14 & $54^{\mathrm{a}}$ & 9 & $49^{a}$ & 11 \\
\hline $\mathrm{LDL}(\mathrm{mmol} / \mathrm{mol})$ & $192^{8, b}$ & 44 & $178^{\mathrm{a}, \mathrm{b}}$ & 33 & $99^{a}$ & 9 & $225^{b}$ & 30 \\
\hline HDL $(\mathrm{mmol} / \mathrm{mol})$ & $751^{\mathrm{a}, \mathrm{b}}$ & 43 & $773^{\mathrm{a}, \mathrm{b}}$ & 26 & $853^{a}$ & 14 & $682^{b}$ & 31 \\
\hline VLDL:HDL & $0 \cdot 10^{\mathrm{a}}$ & 0.05 & $0.07^{\mathrm{a}}$ & 0.02 & $0 \cdot 06^{\mathrm{a}}$ & 0.01 & $0 \cdot 07^{\mathrm{a}}$ & 0.02 \\
\hline LDL:HDL & $0.29^{a}$ & 0.06 & $0 \cdot 23^{\mathrm{a}, \mathrm{e}}$ & 0.05 & $0 \cdot 12^{b . c}$ & 0.01 & $0.33^{a}$ & 0.06 \\
\hline
\end{tabular}

$\mathrm{SO}$, fibre depleted; SC, $60 \mathrm{~g}$ cellulose $/ \mathrm{kg} ; \mathrm{SP}, 100 \mathrm{~g}$ pectin $/ \mathrm{kg} ; \mathrm{SB}, 100 \mathrm{~g}$ wheat $\mathrm{bran} / \mathrm{kg}$. VLDL, very-lowdensity lipoproteins; LDL, low-density lipoproteins; HDL, high-density lipoproteins.

${ }_{a, b, c}$ In a horizontal row, mean values with different superscript letters were significantly different $(P \leqslant 0 \cdot 05$; ANOVA).

Table 3. Effects of dietary fibres on serum and lipoprotein triglycerides and cholesterol in rats fed on a high-fat cholesterol diet $(250 \mathrm{~g}$ fat and $12 \mathrm{~g}$ cholesterol $/ \mathrm{kg})$

(Mean values with their standard errors for nine determinations)

\begin{tabular}{|c|c|c|c|c|c|c|c|c|}
\hline \multirow[t]{2}{*}{ Diet... } & \multicolumn{2}{|c|}{ HFCO } & \multicolumn{2}{|c|}{ HFCC } & \multicolumn{2}{|c|}{ HFCP } & \multicolumn{2}{|c|}{ HFCB } \\
\hline & Mean & $\mathrm{SE}$ & Mean & SE & Mean & $\mathrm{SE}$ & Mean & $\mathrm{SE}$ \\
\hline \multicolumn{9}{|l|}{ Triglycerides } \\
\hline Serum $(\mathrm{mmol} / \mathrm{l})$ & $0 \cdot 98^{\mathrm{a}}$ & $0 \cdot 14$ & $0.84^{\mathrm{a}}$ & $0 \cdot 14$ & $0 \cdot 86^{\mathrm{a}}$ & 0.06 & $0 \cdot 48^{\mathrm{b}}$ & 0.08 \\
\hline VLDL (mmol/1) & $0.94^{\mathrm{a}}$ & $0 \cdot 14$ & $0.69^{a, b}$ & 0.11 & $0.72^{\mathrm{q}}$ & 006 & $0 \cdot 37^{\mathrm{b}}$ & 0.05 \\
\hline \multicolumn{9}{|l|}{ Cholesterol } \\
\hline Serum (mmol/l) & $3 \cdot 36^{\mathrm{a}}$ & 0.25 & $3 \cdot 39^{a}$ & $0 \cdot 21$ & $2 \cdot 80^{\AA}$ & $0 \cdot 16$ & $2 \cdot 82^{\mathrm{a}}$ & 0.17 \\
\hline VLDL (mmol/1) & $1 \cdot 46^{\mathrm{a}}$ & $0 \cdot 18$ & $1 \cdot 51^{\mathrm{a}}$ & $0 \cdot 16$ & $0.97^{\mathrm{b}}$ & $0 \cdot 10$ & $0.94^{\mathrm{b}}$ & 0.12 \\
\hline LDL $(\mathrm{mmol} / 1)$ & $0 \cdot 44^{\mathrm{a}}$ & $0 \cdot 10$ & $0.40^{\mathrm{a}}$ & 0.05 & $0 \cdot 31^{a}$ & 0.06 & $0 \cdot 31^{\mathrm{a}}$ & 0.05 \\
\hline HDL (mmol/1) & $1 \cdot 34^{\mathrm{a}}$ & 0.07 & $1 \cdot 31^{\mathrm{a}}$ & 0.09 & $1 \cdot 31^{\mathrm{a}}$ & $0 \cdot 11$ & $1 \cdot 40^{\mathrm{a}}$ & 0.08 \\
\hline VLDL $(\mathrm{mmol} / \mathrm{mol})$ & $425^{\mathrm{a}}$ & 29 & $441^{\mathrm{a}}$ & 26 & $351^{\mathrm{a}}$ & 29 & $355^{\mathrm{a}}$ & 36 \\
\hline $\mathrm{LDL}(\mathrm{mmol} / \mathrm{mol})$ & $134^{a}$ & 33 & $122^{\mathrm{a}}$ & 13 & $114^{\mathrm{a}}$ & 18 & $117^{\mathrm{a}}$ & 16 \\
\hline $\mathrm{HDL}(\mathrm{mmol} / \mathrm{mol})$ & $435^{a}$ & 29 & $413^{a}$ & 29 & $503^{a}$ & 38 & $528^{a}$ & 51 \\
\hline VLDL:HDL & $1 \cdot 11^{\mathrm{a}}$ & $0 \cdot 15$ & $1 \cdot 19^{a}$ & $0 \cdot 15$ & $0 \cdot 77^{\mathrm{a}}$ & $0 \cdot 15$ & $0.67^{\mathrm{a}}$ & 0.20 \\
\hline LDL:HDL & $0.34^{2}$ & 0.08 & $0 \cdot 31^{a}$ & 0.05 & $0.25^{\mathrm{a}}$ & 0.06 & $0 \cdot 23^{\mathrm{a}}$ & 0.05 \\
\hline
\end{tabular}

HFCO, fibre depleted; HFCC, $60 \mathrm{~g}$ cellulose $/ \mathrm{kg}$; HFCP, $100 \mathrm{~g}$ pectin $/ \mathrm{kg} ; \mathrm{HFCB}, 100 \mathrm{~g}$ wheat bran $/ \mathrm{kg}$. VLDL, very-low-density lipoproteins; LDL, low-density lipoproteins; HDL, high-density lipoproteins.

$\mathrm{a}, \mathrm{b}$ In a horizontal row, values with different superscript letters were significantly different $(P \leqslant 0.05$; ANOVA). 
Table 4. Statistical significance (P) of the effects of basal diets or dietary fibres on serum and lipoprotein triglycerides and cholesterol in rats*

\begin{tabular}{|c|c|c|c|c|c|c|c|}
\hline \multirow[b]{2}{*}{ Diets compared } & \multicolumn{2}{|c|}{ Triglycerides } & \multicolumn{5}{|c|}{ Cholesterol } \\
\hline & Serum & VLDL & Serum & HDL & LDL & VLDL & HDL:VLDL \\
\hline $\begin{array}{l}\text { High-fat cholesterol } v \text {. } \\
\text { standard }\end{array}$ & $<0.05$ & $<0.05$ & $<0.001$ & $<0.05$ & NS & $<0.00 \mathrm{I}$ & $<0.001$ \\
\hline Cellulose $v$. fibre-depleted & NS & NS & NS & NS & NS & NS & NS \\
\hline Pectin $v$. fibre-depleted & $<001$ & $<0.01$ & $<0.001$ & NS & $<0.001$ & $<0.001$ & $<0.05$ \\
\hline $\begin{array}{l}\text { Wheat bran } v \text {. fibre- } \\
\text { depleted }\end{array}$ & $<0.001$ & $<0.001$ & $<0.005$ & NS & NS & $<0.001$ & $<0.005$ \\
\hline Pectin v. cellulose & $<0.005$ & $<0.005$ & $<0.001$ & NS & $<0.005$ & $<0.001$ & $<0.01$ \\
\hline Wheat bran $v$. cellulose & $<0.001$ & $<0.001$ & $<0.001$ & NS & NS & $<0.00 \mathrm{l}$ & $<0.005$ \\
\hline Wheat bran $v$. pectin & NS & $<0.05$ & NS & NS & NS & NS & NS \\
\hline
\end{tabular}

NS, not significant; VLDL, very-low-density lipoproteins; LDL, low-density lipoproteins; HDL, high-density lipoproteins.

* Significant differences are indicated by the probability level calculated by two-way analysis of variance, multivariance analysis and multicomparison methods using contrast analysis (MANOVA).

having lower values for VLDL-cholesterol and LDL-cholesterol. Furthermore, in the SP group, the triglyceride content in the VLDL was lower compared with the SC group but the proportion of triglycerides in the VLDL did not change significantly. The SP group differed from the SO (fibre-depleted) group, having lower values for LDL-cholesterol and LDL-cholesterol: HDL-cholesterol.

The SB ( $100 \mathrm{~g}$ wheat bran $/ \mathrm{kg}$ enriched) group had lower (but not significantly) values for serum triglycerides, serum cholesterol and VLDL-cholesterol compared with SO and SC groups, while VLDL-triglycerides were significantly lower compared with the SC group. The SB group differed from the SP group having higher values for LDL-cholesterol, proportion of LDL-cholesterol, LDL-cholesterol: HDL-cholesterol and lower values for the proportion of HDL-cholesterol. There were no other major differences between the different groups.

\section{Serum lipids and lipoproteins in rats fed on high-fat cholesterol diets}

Differences between the four groups on the high-fat cholesterol diets are shown in Table 3 . Most of the differences seen in the groups fed on the standard diets disappeared when animals were fed on the diet rich in fat and cholesterol, regardless of fibre supplementation. Nevertheless, the serum triglyceride level was significantly lower in the HFCB (100 g wheat bran $/ \mathrm{kg}$ enriched) group compared with the other groups. The triglyceride content in the VLDL of the HFCB group was also significantly lower when compared with the HFCO (fibre-depleted) and HFCP groups (100 g pectin $/ \mathrm{kg}$ enriched). Furthermore, the serum cholesterol value for the HFCP and HFCB groups remained lower compared with the values for the other two groups but the difference was not significant. In addition, the VLDL-cholesterol values of the HFCP and HFCB groups were significantly lower when compared with those of the HFCO and HFCC (60 $\mathrm{g}$ cellulose $/ \mathrm{kg}$ enriched) groups.

HDL-cholesterol was not changed by adding fibre to the high-fat cholesterol diets, while cholesterol ratios LDL:HDL, and more markedly, VLDL:HDL were lowered (but not significantly) when supplementing this diet with pectin or wheat bran. 


\section{Effects of standard diets, high-fat cholesterol diets and the type of dietary fibre on serum lipids and lipoproteins}

The differences between the groups of rats, as estimated by MANOVA, are shown in Table 4. With respect to the influence of diets on lipid contents of serum and lipoproteins (high-fat cholesterol $v$. standard), it appears that the differences between the two diets were significant for all variables considered, except LDL-cholesterol.

With respect to the effect of fibre type, no differences appeared when comparing the cellulose-enriched diet with the fibre-free diet. However, when comparing pectin- and branenriched diets with the fibre-free diet, highly significant differences were found. The same differences were observed when comparing pectin- and bran-enriched diets with the cellulose-enriched diet. In these groups, the differences were significant for all variables considered, except HDL-cholesterol and some of the LDL-cholesterol values. Pectinenriched diets differed only in their VLDL-triglyceride values compared with bran-enriched diets.

\section{DISCUSSION}

The present study confirms the effect of pectin in lowering the cholesterol level in sera of rats receiving a standard balanced diet. This effect has been already observed in rats (Wells \& Ershoff, 1961; Leveille \& Sauberlich, 1966; Chang \& Johnson, 1976; Tsai et al. 1976; Rotenberg \& Jakobsen, 1978; Chen \& Anderson, 1979 b; Reddy et al. 1980; Judd \& Truswell, 1985; Sacquet et al. 1985) and humans (Kay \& Truswell, 1977; Jenkins et al. 1979; Judd \& Truswell, 1982; Durrington et al. 1976; Brydon et al. 1980; Mueller et al. 1983; Mahley \& Holcombe, 1977). More originally, our study shows that pectin also decreases the VLDL- and LDL-cholesterol concentrations and consequently the LDL:HDLcholesterol. The physiological process by which pectin selectively lowers the LDLcholesterol has not been examined. However, it has been reported that molecules which promote an increase in bile-acid secretion induce a decrease in serum LDL levels. Research conducted in our laboratory demonstrated that hepatic secretion of bile salts increased when rats were fed on a diet enriched with pectin (Lafont et al. 1985). Similar results have been obtained by others (Brydon et al. 1980). Thus, hepatic degradation of LDL might be favoured by the enhanced secretion of bile salts observed in rats receiving this diet. In addition, most studies have already demonstrated that, as for the serum cholesterol, the liver cholesterol content decreased when pectin was added to the diet (Wells \& Ershoff, 1961 ; Leveille \& Sauberlich, 1966; Chang \& Johnson, 1976; Tsai et al. 1976; Rotenberg \& Jakobsen, 1978; Chen \& Anderson 1979b; Judd \& Truswell, 1985; Sacquet et al. 1985).

Particular attention must be paid to the effect of pectin on the HDL fraction. In the SP group, a high level of cholesterol in the HDL fraction was maintained even though a reduction in the total cholesterol concentration was observed in serum; this confirms previous findings (Chen \& Anderson, 1979a). Another interesting effect of pectin is the redistribution of the cholesterol among the different classes of lipoproteins. The proportion of cholesterol in the HDL was highest (not significant) in the SP group, and LDL- and VLDL-cholesterol were lower $(P<0.05)$ compared with the SC group. In humans, a negative correlation was observed between the amount of HDL-cholesterol and the occurrence of cardiovascular diseases (Miller et al. 1976; Gordon et al. 1977).

It is of particular interest to note that the effect of pectin in lowering serum cholesterol concentrations was not significant in the rats fed on the high-fat cholesterol diet. In fact, it has been previously shown that pectins hardly lowered serum cholesterol in rats fed on a high-fat diet (Chang \& Johnson, 1976; Asp et al. 1981; Mueller et al. 1983; Judd \& Truswell, 1985). A comparable lack of effect was also observed in rats receiving the high- 
fat cholesterol diet containing bran. Nevertheless, in these groups, the distribution of cholesterol among the different classes of lipoproteins was affected, especially VLDLcholesterol. Both dietary fat and cholesterol change the lipoprotein content and affect specific classes of lipoproteins. These changes have been described in the literature (Mahley \& Halcombe, 1977; Worthington \& Miller, 1983). Similar changes occurred in the experimental animals. The most drastic change was a reduction in the typical HDL level, reflected by the cholesterol level in HDL, and an increase in the level of apo B-containing lipoproteins (VLDL and LDL). Under the conditions of the present study, low-methoxyl pectin and wheat bran were able to affect the cholesterol distribution among the lipoproteins. In particular, HFCP and HFCB groups had a higher (but not significant) proportion of cholesterol in the HDL fraction. In only one previous study in rats (Asp et al. 1981) has wheat bran been shown to change the cholesterol distribution in lipoprotein classes by increasing HDL-cholesterol with a high-fat diet. In most other studies (Wells \& Ershoff, 1961; Chen \& Anderson, 1979 a; Van Beresteyn et al. 1979; Nomani et al. 1981) no significant changes were obtained when wheat bran was added to a balanced or moderately high-fat diet, as we observed with the standard diet.

Many studies have documented the lowering effect of plant fibres on serum cholesterol concentration in humans and animals, but results concerning serum triglycerides are more controversial. This might be due to the large discrepancy between the various experimental diets tested; the present study was specifically performed to evaluate the effect of fibre when added either to a low-fat diet or to a high-fat cholesterol diet. Under the experimental conditions in the present study, a significant reduction in serum and VLDL-triglycerides occurred in rats fed on pectin or bran. However, pectin significantly lowered the triglyceride values only when rats were fed on the standard diet, in agreement with previous findings (Chang \& Johnson, 1976; Rotenberg \& Jakobsen, 1978; Chen \& Anderson, $1979 a$; Mueller et al. 1983), while wheat bran exerted a much more marked effect in the case of the highfat cholesterol diet. Although this effect of wheat bran has been obtained with fasted (Chen \& Anderson, 1979a) and non-fasted rats (Lemonnier et al. 1983), it was not found by other workers (Van Beresteyn et al. 1979; Vahouny et al. 1980; Asp et al. 1981).

Two-way analysis of variance showed that the groups fed on the fibre-depleted diet behaved similarly to those fed on the purified cellulose-enriched diets. These two experimental groups represent, in fact, two different kinds of control diet, the former being artificially depleted of any indigestible material while the latter were provided with a moderate amount $(60 \mathrm{~g} / \mathrm{kg})$.

The two-way analysis of variance clearly demonstrated that pectin and bran were determinant for triglyceride and cholesterol levels in serum, VLDL and LDL. It is generally assumed that pectins are more effective than cereal brans in modifying serum cholesterol or triglyceride levels. In fact, these effects could be modulated by the basal diets, giving conflicting results in rats as well as in man. The present study showed that low-methoxyl pectin and wheat bran might act specifically, depending on the basal diet, but as a whole (Table 4) do not differentiate in their main effects on serum lipid and lipoprotein indices with one exception (VLDL-triglycerides).

Pectins and wheat bran might both bind bile salts, phospholipids and cholesterol (Lairon et $a l .1985 b$ ) but to an extent too low to induce significant metabolic effects. In fact, the possible mechanisms by which pectins and wheat brans might modify cholesterol and triglyceride metabolism may be discussed in the light of the differences observed in the present work with the two kinds of basal diet.

Pectins modify cholesterol and triglyceride variables in the rat mainly in the presence of a low-fat diet, as shown in the present study and in previous reports (Chang \& Johnson, 1976; Judd \& Truswell, 1985). The effects of pectins might be due to induced changes in 
the viscosity of intestinal contents, a property directly linked to the molecular properties of the different pectins (Isaksson et al. 1982; Judd \& Truswell, 1985). Moreover, pectins might alter the ultrastructure and some functions of the intestinal mucosa (Cassidy et al. 1981; Jacobs, 1983). These combined influences might impair or delay the intestinal absorption of cholesterol (Hyun et al. 1963; Leveille \& Sauberlich, 1966; Reddy et al. 1980; Judd \& Truswell, 1985; Sacquet et al. 1985) and fats (Isaksson et al. 1983; Sandberg et al. 1983; Judd \& Truswell, 1985), decrease intestinal lipid synthesis (Schwartz et al. 1983) and lower the lymph lipid output (Hyun et al. 1963; Vahouny et al. 1980). This might in turn decrease the liver cholesterol and triglyceride accumulation and promote beneficial changes in serum lipid and lipoprotein patterns. Thus, low-methoxyl pectin might have a less pronounced effect than high-methoxyl pectin (Judd \& Truswell, 1985) and a high-fat cholesterol diet would tend to marginalize these effects, as observed in the present study and reported earlier (Chang \& Johnson, 1976; Judd \& Truswell, 1985).

On the other hand, wheat bran, with few exceptions (Chen \& Anderson, 1979 a), hardly modifies the serum-lipid variables when rats are fed on a low-fat diet, whereas liver accumulation might be lowered (Chen \& Anderson, 1979a; Van Beresteyn et al. 1979; Nomani et al. 1981 ; Sacquet et al. 1982; Schneeman et al. 1984). With a high-fat diet, some lipoprotein variables might be modified following bran supplementation. Thus, wheat bran might exert an effect mainly when lipid metabolism is disturbed by a high-fat diet or preexistent hyperlipidaemia (Heaton \& Pomare, 1974; Lingarde \& Larsson, 1984; Kies, 1985; Salvioli et al. 1985). We have recently shown in vitro (Lairon et al. $1985 a, b$ ) that wheat bran may drastically inhibit the hydrolytic activity of pancreatic lipase on triglycerides, in agreement with other findings showing a large increase in the lipid ileal output with wheat bran supplementation in rats (Isaksson et al. 1983). This inhibitory effect is probably reinforced in vivo by the well-known accelerating effect of bran on the transit time. Given the normal excess amount of pancreatic lipase in the upper small intestine, the inhibitory effect of wheat bran on triglyceride lipolysis should be significant only in the presence of a high-fat diet or, as shown in humans, in the case of pancreatic insufficiency (Isaksson et al. 1984). In these cases, intestinal fat absorption and possibly cholesterol absorption might be slowed, giving the observed beneficial metabolic changes.

In conclusion, it would be of great importance to explore further the mechanisms by which pectins and cereal brans modify fat or cholesterol assimilation and metabolism, under different basal diets or lipid status. Combinations of pectins and cereal brans in the diet could be useful in normalizing cholesterol and triglycerides of patients suffering from dislipidaemia.

This work was supported by a grant from the Délégation Génerale à la Recherche Scientifique et Technique (DGRST, grant no. 80.7.0116). The authors wish to thank J. P. Durbec for his help in the statistical analysis of the results.

\section{REFERENCES}

Amic, J., Lairon, D. \& Hauton, J. C. (1972). Clinica Chimica Acta 40, 107-114.

Anderson, J. W. \& Chen, W. (1979). American Journal of Clinical Nutrition 32, 346-363.

Asp, N. G., Bauer, H. G., Nilsson-Ehle, P., Nyman, M. \& Oste, R. (1981). British Journal of Nutrition 46, $385-393$.

Brydon, W. G., Tadesse, K., Eastwood, M. A. \& Lawson, M. E. (1980). British Journal of Nutrition 43, $101-106$.

Burstein, M., Scholnick, H. R. \& Morfin, R. (1970). Journal of Lipid Research 11, 583-595.

Cassidy, M. M., Lightfoot, F. G., Grau, L. E., Story, J. A., Kritchevsky, D. \& Vahouny, G. V. (1981). American Journal of Clinical Nutrition 34, 218-228.

Chang, M. L. W. \& Johnson, M. A. (1976). Journal of Nutrition 106, 1562-1568.

Chen, W. J. L. \& Anderson, J. W. (1979a). Journal of Nutrition 109, 1028-1034. 
Chen, W. J. L. \& Anderson, J. W. (1979 b). Proceedings of the Society for Experimental Biology and Medicine 162, $310-313$.

Durrington, P. N., Manning, A. P., Bolton, Ch \& Hartog, M. (1976). Lancet ii, 394.

Gibson, J. C., Rubinstein, A. \& Brown, W. V. (1984). Clinical Chemistry 30, 1784-1788.

Gordon, T., Castelli, W. P., Hjortland, M. C., Kannel, W. B. \& Dawber, T. R. (1977). American Journal of Medicine 62, 707-714.

Havel, R. J., Eder, H. A. \& Bragdon, J. H. (1955). Journal of Clinical Investigation 34, 1345-1353.

Heaton, K. W. \& Pomare, E. W. (1974). Lancet i, 49-50.

Hyun, S. A., Vahouny, G. V. \& Treadwell, C. R. (1963). Proceedings of the Society for Experimental Biology and Medicine 112, 496-501.

Isaksson, G., Asp, N. G. \& Ishe, 1. (1983). Scandinavian Journal of Gastroenterology 18, 417-423.

Isaksson, G., Lundquist, I., Akesson, B. \& Ishe, I. (1984). Scandinavian Journal of Gastroenterology 19, $467-472$.

Isaksson, G., Lundquist, I. \& Ihse, I. (1982). Gastroenterology 82, 918-924.

Jacobs, L. R. (1983). American Journal of Clinical Nutrition 37, 954 960.

Jenkins, D. J. A., Reynolds, D., Leeds, A. R., Waller, A. L. \& Cummings, J. H. (1979). American Journal of Clinical Nutrition 32, 2430-2435.

Judd, P. A. \& Truswell, A. S. (1982). British Journal of Nutrition 48, $451-458$.

Judd, P. A. \& Truswell, A. S. (1985). British Journal of Nutrition 53, 409-425.

Kay, R. M. (1982). Journal of Lipid Research 23, 221-242.

Kay, R. M. \& Truswell, A. S. (1977). American Journal of Clinical Nutrition 30, 171-175.

Kies, C. (1985). Lipids 20, 802-807.

Kritchevsky, D. \& Tepper, S. A. (1968). Journal of Atherosclerosis Research 8, 357-369.

Kromhout, D., Bosschieter, E. B. \& Delezene Coulander, C. (1982). Lancet ii, 518-522.

Lafont, H., Lairon, D., Vigne, J. L., Chanussot, F., Chabert, C., Portugal, H., Pauli, A. M., Crotte, C. \& Hauton, J. C. (1985). Journal of Nutrition 115, 849-855.

Lairon, D., Borel, P., Termine, E., Grataroli, R., Chabert, C. \& Hauton, J. C. (1985a). Nutrition Reports International 32, 1107-1113.

Lairon, D., Lafont, H., Vigne, J. L., Nalbone, G., Leonardi, J. \& Hauton, J. C. (1985b). American Journal of Clinical Nutrition 42, 629-638.

Lemonnier, D., Doucet, C. \& Flament, C. (1983). Cahiers de Nutrition et Diététique 17, 99-100.

Leveille, G. A. \& Sauberlich, M. E. (1966). Journal of Nutrition 88, 209-2I4.

Lingarde, F. \& Larsson, L. (1984). Human Nutrition: Clinical Nutrition 38C, 39-45.

Mahley, R. W. \& Holcombe, K. S. (1977). Journal of Lipid Research 18, 314-324.

Miller, G. J., Miller, N. E. \& Ashcroft, M. T. (1976). Clinical Science and Molecular Medicine 51, 475481.

Mueller, M. A., Cleary, M. P. \& Kritchevsky, D. (1983). Joumal of Nurition 113, 2229-2238.

Nomani, M. Z. A., Syed Hussain, S. S., Lim, J. K., Albrink, M. J., Gunnells, C. K. \& Davis, G. K. (1981). American Journal of Clinical Nutrition 34, 2078-2087.

Reddy, B. S., Watanabe, K. \& Sheinfil, A. (1980). Journal of Nutrition 110, 1247-1254.

Rotenberg, S. \& Jakobsen, P. E. (1978). Journal of Nutrition 108, 1384-1392.

Rush, R. L., Leon, L. \& Turrel, J. (1970). Congress 1970/Clinical Analysis vol. 1, pp. 503-507. New York: Futura

Sacquet, E., Leprince, C. \& Riottot, M. (1982). Reproduction, Nutrition, Développement 22, $291-305$.

Sacquet, E., Leprince, C., Riottot, M. \& Raibaud, P. (1985). Reproduction, Nutrition, Développement 25, 93-100.

Salvioli, G., Lugli, R. \& Pradelli, J. M. (1985). Digestive Diseases Science 30, 301-307.

Sandberg, A. S., Ahderinne, R., Andersson, H., Hallgren, B. \& Hulten, L. (1983). Human Nutrition: Clinical Nutrition 37C, 171-183.

Schneeman, B. O., Cimmarusti, J., Cohen, W., Downes, L. \& Lefevre, M. (1984). Journal of Nutrition 114. $1320-1326$.

Schwartz, S. E., Starr, C., Bachman, S. \& Holtzapple, P. G. (1983). Journal of Lipid Research 24, $746-752$.

Trowell, H. (1972). American Journal of Clinical Nutrition 25, 926-932.

Tsai, A. C., Elias, J., Kelley, J. J., Lin, R. S. C. \& Robson, J. R. (1976). Journal of Nutrition 106, 118-123,

Vahouny, G. V., Roy, T., Gallo, L. L., Story, J. A., Kritchevsky, D. \& Cassidy, M. (1980). American Journal of Clinical Nutrition 33, 2182-2191.

Van Beresteyn, E. C. H., Van Schaik, M. \& Kerkhof Mogot, M. F. (1979). Journal of Nutrition 109, 2085-2097.

Wells, A. F. \& Ershoff, B. H. (1961). Journal of Nutrition 74, 87-92.

Worthington, R. E. \& Miller, J. (1983). Nutrition Reports International 28, 1361-1368. 